\title{
4 \\ Ethics and politics in the New Atlantis
}

\author{
D A VID COLCLOUGH
}

God forbid that we should give out a dream of our own imagination for a pattern of the world; rather may he graciously grant to us to write an apocalypse or true vision of the footsteps of the Creator imprinted on his creatures. ${ }^{\mathrm{I}}$

The New Atlantis is a text about natural philosophy which seems to offer connections at almost every point with moral and political philosophy. The celebrated description of Salomon's House raises the question of the place of the scientist in society and the allusion to Plato's Critias and Timaeus in the work's title suggests an engagement with that philosopher's description of the ideal state. ${ }^{2}$ Furthermore, a reference to More's Utopia, together with the recognisably 'utopian' framework of the narrative, promises responses to other 'best state' exercises, perhaps including Andreae's Christianopolis (I6I9) and Campanella's Civitas Solis (I623). ${ }^{3}$ Bacon's own political activities are well known, and in successive editions of the Essays, as well as in his speeches and pieces of advice, he had shown himself willing and able to treat what he considered the most pressing issues of political and ethical theory and practical negotiation. Nor was this engagement halted by Bacon's disgrace in I62 $\mathrm{r}$ : in the years after his fall from office, he wrote a series of works which could be read as attempts to regain favour and political influence; the New Atlantis could 
well be read as an unfinished contribution to this project. Finally, the New Atlantis was drawn upon by Gabriel Plattes in his starkly utilitarian Macaria of I64I in apparent testimony to the political applicability of Bacon's text, ${ }^{4}$ while Salomon's House was imitated by both the mid-century republicans and the monarchist founders of the Royal Society. ${ }^{5}$

However, when one turns to the text itself, the ethical and the political are above all striking by their absence. Even the prefatory note attached to the work by Bacon's chaplain, William Rawley, draws attention to its failure to provide a fully fledged utopian vision, asserting (however unreliably) that 'his Lordship thought also in this present fable to have composed a frame of Laws, or the best state or mould of a commonwealth; but foreseeing that it would be a long work, his desire of collecting the Natural History diverted him. ${ }^{6}$ Natural history is privileged above political theory, just as the New Atlantis itself, 'A Worke unfinished', is placed at the end of the volume containing the Sylva Sylvarum, natural history collected from a mixture of observation and reading. In the New Atlantis, the practice of science appears to be kept institutionally and geographically separate from politics, with considerable autonomy being given to the scientific community. ${ }^{7}$ While in More's work Hythloday offers a detailed description of Utopia's geography, government and laws, the moral philosophy of the inhabitants and their domestic or oeconomic arrangements, and while the island narrative of Book II is used as an example of a specific moral and political argument (that private property should be abolished), readers of the New Atlantis remain ignorant of most of these aspects of Bensalem. ${ }^{8}$ There is a remarkable lack of detail about the nature of the island, other than that it is 'five thousand six hundred miles in circuit, and of rare fertility of soil in the greatest part' $(469-70)$. As far as its constitution and administration are concerned, we know of Solamona's laws concerning strangers, and that he established other 'fundamental laws' (470), but we are not told what they are; 'the king' is mentioned at page 474, but we know nothing of his rule or his government. The only insight we gain into the oeconomical governance of the island is the curious Feast of the Family (472-5); no ethical system is outlined and most of the disturbing questions posed to moral philosophy at 
the time of the text's composition are glossed over, if not ignored. The islanders exist in a vaguely outlined but allegedly desirable state of peace, political contentment, and Christian-Hebraic virtue, which fosters or is fostered by the natural philosophical researches of Salomon's House. The 'Fathers' of this research institution are venerated and appear in magnificent procession, but their specific place in the social hierarchy and the precise extent of their authority remains unclear.

If we consider the ground rules for a best-state exercise laid down in Book VII of Aristotle's Politics, the problems become even clearer. Aristotle writes that 'he who would duly inquire about the best form of a state ought first to determine which is the most eligible life. ${ }^{9}$ At a pinch, the New Atlantis could be regarded as an attempt to describe this life as it might be lived, rather than to list the component virtues of which it should consist. But this begs the further question of how to decide whether such a hazily described life as that of the people of Bensalem can properly be assessed as conducive or otherwise to eudaimonia, which Aristotle has deemed in the Ethics to be the aim of life. ${ }^{\text {Io }}$

I would suggest, in contrast, that to attempt to read the New Atlantis as a utopia in the Morean mould and to search the text for a system of, or even a series of sententiae about, ethics or politics, is misguided. Bacon's response to the textual tradition of Aristotle, Plato and More consists here in a manipulation of certain formal features to very different ends from theirs. Expectations are raised in the reader, and deliberately, I would argue, disappointed. Bacon seems to be aware of the kinds of questions readers might ask about this imaginary society and to half-answer each of them. The end result might be - although this has singularly failed to happen in many scholarly interpretations of the text that the reader becomes aware that they are asking the wrong questions of the work. Ian Box, who is also puzzled by the absence from the New Atlantis of the kind of political and ethical thought which makes up the Essays, ascribes this gap to a fundamental contradiction between Bacon's identities as a 'scientist' and a 'statesman'. ${ }^{\text {II }}$ It is certainly clear from several of his works that Bacon found a degree of incommensurability between ethical (specifically Christian) and civic values, ${ }^{\mathrm{I} 2}$ and that many of the conditions praised in his natural philosophy are condemned 
elsewhere in his writings. Markku Peltonen stresses that the repeated identification of Bacon's philosophical with his political thought relies upon a 'rhetorical similarity' which can obscure the distinction Bacon makes between those qualities and values that are required for the advancement of sciences and those needed for political success. ${ }^{13}$ While in his works on the pursuit of greatness Bacon stresses the importance of a large armed populace engaged in regular warfare, he frequently emphasises that the advancement of learning demands peace, international co-operation and the absence of religious controversy. ${ }^{14}$ Rather than reading Bacon's wide-ranging writings into an unhappily homogeneous unity, it is better to think of each work as making a different and specific intervention into a particular debate. ${ }^{15}$

II

Bensalem, the island whose name means 'son of peace', conforms, as it soon becomes clear in the New Atlantis, to virtually all of Bacon's social and political criteria for the reform of knowledge. ${ }^{16}$ Its peacefulness is unrivalled, the only military encounter mentioned being the ancient attack by the Coyans (Peruvians), which was foiled by the Bensalemite King Altabin. Even his victory was a peaceful one: 'after they were at his mercy, contenting himself only with their oath that they should no more bear arms against him, [he] dismissed them all in safety' (468). The conditions of the sailors' landing similarly suggest the peacefulness of the society: they are asked to swear that they 'are no pirates' and that they have not 'shed blood lawfully or unlawfully within forty days

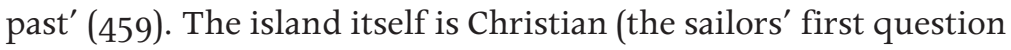
to the Governor of the Strangers' House is how the conversion took place), but free of the confessional division that rent contemporary Europe. Moreover, freedom of worship is extended to the Jews, who were expelled from England in I290 (though the narrator is careful to point out that the Jews of Bensalem 'are of a far differing disposition from the Jews in other parts' $\left.\left(475^{-6}\right)\right){ }^{17}$ In the first part of the text there is a striking preponderance of Biblical references, from the providential arrival of the sailors at Bensalem to their frequent invocation of Scriptural passages, specifically the psalms. For example, in a reference to Psalm 
I37:6 which suggests an equivalence between Bensalem and Jerusalem, the sailors swear to the Governor of the Strangers' House that 'our tongues should first cleave to the roofs of our mouths, ere we should forget either his reverent person or this whole nation in our prayers' $(463) \cdot{ }^{18}$ References to Solomon, who both is and is not the lawgiver Solamona, abound, while Salomon's House, which is named after the Biblical king, is also known as the College of the Six Days' Works, a typical example of Bacon's insistence that the new philosophy should proceed through faith in God's creation, and of his fascination with hexaemeral schemes (The Great Instauration was conceived in six parts). ${ }^{19}$ It is Salomon's House, the 'noblest foundation [...] that ever was upon the earth' (47I), which above all demonstrates that the island of Bensalem is the ideal scientific polity. As has been pointed out many times in the past, this is just the sort of research institution whose establishment Bacon dreamt of for Jacobean England. ${ }^{20}$ Established by a monarch and a central part of the state (indeed, the 'very eye' and the 'lanthorn of this kingdom' $(464,47 \mathrm{I})$ ), it both provides the long-anticipated 'fruits' of the new philosophy and proceeds according to rigorously Baconian methods.

Despite conforming almost perfectly to Bacon's prescriptions of the ideal conditions for the advancement of knowledge, Bensalem diverges from them in one crucial matter, namely the international co-operation whose importance Bacon increasingly stressed and sought through the translation of several of his works into Latin and European vernaculars. ${ }^{21}$ The Bensalemites clearly require assistance from overseas: we are twice told of the twelve-yearly expeditions of the 'Merchants of Light', who venture abroad 'under the names of other nations' and investigate 'the sciences, arts, manufactures, and inventions of all the world', bringing back 'books, instruments, and patterns' (47I; cf. 486). This process has been much remarked upon, partly no doubt because it is one apparently explicitly political aspect of the New Atlantis. Critics have tended to regard the secret expeditions as highly exploitative, and as an example of ruthless political control allegedly concealed beneath Bensalem's apparent perfection. ${ }^{22}$ Thus Charles Whitney contends that while 'on the literal level [...] Bensalem, seems to be sustained by a covert form of colonization', 'allegorically' it offers 'an ideal colonialist solution 
to the challenge of empire facing Britain in the early seventeenth century' and 'an apt analogy for the ideally exploitative class relationship between scientists and the artisans and mechanics whose inventive skills and useful devices Bacon would harness' ${ }^{23}$

So is this the real political import of the text? Is the ideal Baconian state 'linked inseparably to external and even internal colonization', as Whitney would have us believe? ${ }^{24}$ The activities engaged in by the Merchants of Light are not immediately recognisable as those of colonists: they do not attempt to establish settlements in the countries they visit, nor to subdue local cultures or peoples, nor to impose themselves or their Bensalemite customs. Rather, they attempt to assimilate themselves within their host community as successfully as possible in order to keep their origins secret. Far from attempting to 'buy' or simply claim parts of land so that local produce can be exported, they instead behave in strikingly merchant-like fashion, buying whatever provisions or objects they need and rewarding those who have been of service to them. It is, of course, the very secrecy and the supposed inequality of these transactions that has exercised critics. They argue that money is handed over by the Merchants of Light in return for information and equipment which is of much greater use to the members of Salomon's House than it is to those who sell it. Beads are exchanged for gold, in an encounter typical of imperialist enterprise through the ages. ${ }^{25}$

This interpretation of the Merchants of Light, however, is rather simplistic. Certainly, these knowledge-gathering voyages of the merchants resemble small military or mercantile sorties, but given their striking difference from most colonial endeavours, their most interesting aspect is surely their commodification of knowledge. Knowledge is like, and yet unlike, other mercantile commodities; 'thus,' says the Governor of the Strangers' House, 'you see we maintain a trade, not for gold, silver, or jewels; nor for silks; nor any commodity of matter; but only for God's first creature, which was Light: to have light (I say) of the growth of all parts of the world' (472). This is not a colonial relationship to the knowledge the Merchants find on their travels, even if it is possibly an exploitative one.

Exploitative or not, Bensalem's trade and foreign policies are indisputably isolationist, and the divergence from Bacon's praise 
of co-operation thus remains unresolved. The reason, I would argue, is that once again we may be approaching Bacon's 'fable' (as Rawley described it) in the wrong way. This is, after all, a fable, a fiction. For the remainder of this chapter I will argue that it is a fable about knowledge and about reading, about the past and the future, far more than it is a description of an ideal 'feigned commonwealth'. We have noted that in his description of the mercantile acquisition of knowledge from other societies, Bacon implies that those societies are less 'developed' or sophisticated in natural philosophy than Bensalem. Nonetheless, their 'light' is still valuable. This relationship is strikingly similar to Bacon's frequently articulated attitude towards - and use of - the texts of the ancients and other philosophers, which he regards as flawed. Bacon attached a great deal of importance to the kind of naming and shaming exercise undertaken in the Temporis partus masculus of c. 1602-03, where he attacks, one by one, the 'sham philosophers' of the past, and he is often concerned to dismiss out of hand the works and methods of Aristotle in particular and the 'ancients' in general. But he also repeatedly draws upon their works in the process of representing himself as an uncommonly privileged reader, able to winnow the wheat of wisdom from the chaff of false methodology. His allegorical reinterpretation of classical myths and fables in De sapientia veterum (I6og) is characteristic of this strategy, as is his juxtaposition in the Sylva Sylvarum and natural histories (e.g. Historia Ventorum, Historia Vitae et Mortis, published 1622-23) of the results of experiments with 'facts' drawn from Pliny, della Porta and others. ${ }^{26}$ Just as the 'light' bought by Bensalem's merchants is valuable despite being under-used or not even recognised for what it is by its vendors, so the fact that the methods and even the conclusions of the ancients may be inadequate or inaccurate does nothing to prevent us from seeing that much can still be gleaned from their works through an eclectic approach such as that displayed by Bacon throughout his writings.

Bensalem's use of the Merchants of Light thus represents the proper Baconian relationship of the present to the past, and of the natural philosopher to his 'ancient' forebears. This reading relationship is one of re-use and re-appropriation; it is an active, pragmatic and purposeful form of interpretation that Bacon regularly 
elevated over the passive reception of a text's accepted meaning. In the New Atlantis, as elsewhere, Bacon points to the generative possibilities of reading the past as it is figured by the present. This process comprises the active appropriation of texts through an act of incorporation whereby the texts of the past come to make up the body of the writer, but are themselves transformed by being deployed to new ends. ${ }^{27}$ The task of the seventeenthcentury natural philosopher, he declares, is to enter into trade with, rather than to seek conquest over, the books and knowledgesystems of the past, just as the Bensalemites do with their Merchants of Light. If we pursue this allegory, the New Atlantis thus offers in Bensalem a picture of how the future could be if only Bacon's readers take his lesson and recognise both the central importance of natural philosophy to the best life and the vital importance of the Baconian method as expressed in his other writings.

\section{III}

It is not only the description of the Merchants of Light that may be read as a model of reading and of the proper use of knowledge. The text as a whole is susceptible to such an interpretation, and, I would hazard, makes much more sense if read in this way than if we treat it as a transparent description of a model society. There is a distinct lack of individuals through whom ethical questions may be pursued because the text is concerned with problems of thought and of knowledge rather than with the description of the individuals who might do the thinking. As Michèle Le Doeuff has written, both personal identity and the knowing subject are absent from the text. ${ }^{28}$ In this way, it goes beyond that eradication of the private sphere, which J. C. Davis has described as a crucial component of utopian texts in this period. ${ }^{29}$

Bensalem, as I have suggested, may be interpreted as a representation of the Baconian future, in a fruitful 'trading' relationship with the textual past. This makes even more sense if we consider Bensalem as at least in part the model of the ideal Baconian mind, and as exemplifying certain precepts expressed in other Baconian texts concerning the encounter with the new philosophy. The reformation of the subject necessary for the pursuit of this new philosophy consists, for Bacon, in the eradication of mental 
impediments - the smashing of various 'idols', or habits of thought. ${ }^{30}$ In Temporis partus masculus, Bacon attempts to find a means for the promulgation of the new philosophy and to work out how it could be accepted by his contemporaries, writing that: 'when all the entrances and approaches to men's minds are beset and blocked by the most obscure idols [...] A new method must be found for quiet entry into minds so choked and overgrown. ${ }^{31}$ Throughout his discussions of this insinuative pedagogy, however, Bacon is beset by a paradox: in order to clear the mind of its 'idols', one must understand the new philosophy; but in order to understand the new philosophy, one's mind must have been cleared. As the speaker puts it at the end of Temporis partus masculus,

if I should ask you to grapple immediately with the bewildering complexities of experimental science [Experientiae] before your mind has been purged of its idols, beyond a peradventure you would promptly desert your leader. Nor, even if you wished to do so, could you rid yourself of idols by simply taking my advice without familiarising yourself with nature..$^{22}$

One of Bacon's strategies for describing the entry of new knowledge into the mind is to contrast it with the image of a wax tablet. In the same text he explains that 'On tablets, unless you have wiped out the earlier things, you will not write other things. In the mind it is otherwise: unless you write other things, you will not have wiped out earlier things.' 33 The passage is echoed closely in Redargutio philosophiarum, in a typical instance of Baconian self-quotation: 'certainly, on wax tablets you will not write other things unless you will have wiped out the earlier things; in the mind you will scarcely have wiped out the earlier things unless you write in other things.' 34 Once again, Bacon describes a rather more sophisticated conception of the pars destruens of his philosophy than is usually acknowledged by his critics: the old certainly must be surpassed, he states, but this can only be done by letting in the new. The old is thus required as a foundation. The mind cannot be transformed into a clean slate with which the whole process of learning can begin again; those authorities and traditions which are to be rejected are entirely necessary, and it is better that they should be rejected than that they should never have been known at all. The minds of those 
who would follow Bacon thus need neither to be solely reliant upon accepted traditions and modes of thought nor upon the desire for new knowledge, but rather should be open and exploratory as well as aware of the foundations of their knowledge, however jerry-built they might be. ${ }^{35}$ It seems clear that Bacon saw his reformation of knowledge, his 'instauration', as divided into, on the one hand, developing a method or logic whereby nature might best be perceived as it is and, on the other, discovering a means by which this new method and new knowledge could be accepted by the corrupt minds of his contemporaries. At the beginning of the Novum Organum (I620) he writes:

such then are the provisions I make for finding the genuine light of nature and kindling and bringing it to bear. And they would be sufficient of themselves, if the human intellect were even, and like a fair sheet of paper with no writing on it. But since the minds of men are strangely possessed and beset, so that there is no true and even surface left to reflect the genuine rays of things, it is necessary to seek a remedy for this also. ${ }^{36}$

It is this remedy that the New Atlantis is meant, at least in part, to provide. Bacon makes the text into a fable with a philosophical imperative by describing the Bensalemites not simply as a variety of perfect human beings with minds 'like a fair sheet of paper,' or like a wax tablet, but as representatives of the Baconian mind in action. Unlike the inhabitants of Aldous Huxley's Island, left to work out perfection entirely in isolation through the efforts of their own reason in a latter-day Rousseau-esque fable, the Bensalemites use their island state as a basis for exploration and exploitation of other forms of knowledge. They require the past and its errors or half-truths, and, being in an ideal naturalphilosophical state, they are able to take them a step (or several leagues) further towards 'finding the genuine light of nature' ${ }^{37}$

The sailors, by contrast, are at an earlier stage: they are voyagers into the future, somewhat like Bacon himself, at first dazzled and almost struck dumb by what they see and hearthey are, after all, as the narrator states in terms that extravagantly exceed the geographical, 'beyond both the old world and the new' (46r). The narrator describes their reaction to the account of the Merchants of Light in precisely these terms: 'when [the Governor of the Strangers' House] had said this, he was silent; 
and so were we all. For indeed we were all astonished to hear so strange things so probably told' (472). This state of confused awakening is also described at the conclusion of the Redargutio philosophiarum, where the audience of the lecture reported in the text discuss what they have heard: 'they talked to one another saying that they were like men who had come suddenly out of thick shade into the open light and were for the moment dazzled, but carried with them a sure and happy augury of better sight to come' $.3^{8}$ In the Novum Organum, moreover, Bacon compares the entrance into the 'kingdom of man' via the new natural philosophy to that into the kingdom of heaven, 'whereinto none may enter except as a little child': the sailors are those innocents, denied even names or nationality. ${ }^{39}$

Bensalem is thus the future of natural philosophy in both its methodological and its instrumental form (the latter being described in detail through Salomon's House). ${ }^{\circ}$ As I have suggested above, in describing this future Bacon is concerned to stress its attainability, abiding by Aristotle's dictum that 'in framing an ideal we may assume what we wish, but should avoid impossibilities' ${ }^{4 \mathrm{I}}$ In attempting to demonstrate the shape of natural philosophy to come, though, Bacon goes further than this, as is evident from my epigraph: there he explicitly rejects the utopian project, associating it implicitly with those ways of thinking which derive from the passions and preoccupations of the individual rather than from the facts of nature. A little later in the Novum Organum he writes that 'the human mind is no dry light, but receives an infusion from the will and affections; whence proceed sciences which may be called "sciences as one would".' $4^{2}$ The New Atlantis is not to be read as 'science (or society) as Bacon would' so much as 'thought as it might be practised'.

The ethical and political, both in terms of the detailed description of an ideal commonwealth and of recommended codes of conduct, are thus absent partly because Bacon is offering a model of the use of knowledge and reading for any society (even if most specifically seventeenth-century England), rather than a model of a new, perfect society. A more perfect society may well result from this, it is implied, but it is the better society which is consequent on the reform of knowledge rather than new knowledge which results from a reformed or transformed society. In the 
epigraph to this chapter Bacon expresses his concern that instead of an imaginative utopia, 'the best state or mould of a commonwealth', the natural philosopher should be committed to writing an apocalypse, or revelation of divine secrets in nature: the speech of the Father of Salomon's House is just such a discourse, but so is the rest of the text, in extenso. ${ }^{43}$ The politics of the New Atlantis are above all those of conservative reform; but conservative, it would appear from the paucity of material support given to Bacon's plans, and of vocal support to his methodological treatises, only in the mind of the writer. ${ }^{44}$ It is difficult to over-emphasise Bacon's determination that his mental and institutional reforms were within reach: for all the exoticism of Bensalem as another New World 'discovery', critics have perhaps thought too much in terms of the wonder of the new colonies and not enough about the implications of the analogy for Bacon's argument about the advancement of learning. The point is surely not that Bensalem is so distant as to be necessarily imaginary, but that it is, in the context of recent voyages, eminently probable. ${ }^{45}$ Bacon's ship on the title page of the Novum Organum, we can hardly forget, sails proudly through the Pillars of Hercules, extending the bounds of the known world: his oft-repeated (mis)quotation of Daniel I2:4 prophesies that 'many shall go about and knowledge will be increased.' ${ }^{6}$ That this image of the future should be more or less universally applicable to almost any readership Bacon may have envisaged for his text is shown by the confessional and national anonymity of the sailors. That it is intended to appeal to those readers as singling out their culture in particular (whatever it may be) is illustrated by the direct address of the narrator and his frequent reference to things which are almost, but not quite, like those to be encountered in Europe: a medicinal fruit is 'like an orange, but of colour between orange-tawny and scarlet', and so on. ${ }^{47}$ In this way, the New Atlantis is a notably more didactic and monologic work than More's Utopia, where Hythloday's insistence that the abolition of private property is the key to happiness is questioned, undermined, and ironised just as much as are More's insistence to the contrary and arguments about the importance of becoming a counsellor. Many writers have seen in the description of the Father of Salomon's House a wistful self-portrait of the author, 
and there is some truth in this; but to me the force of the description is in Bacon's conviction that such a role could be filled by one such as himself, not in the pathos of the selfdelusion that it is purported to represent. The narrator of the New Atlantis writes of Bensalem that if there be a mirror in the world worthy to hold men's eyes, it is that country' (472): the mirror is intended, as in the literature of the speculum principis tradition, to serve a dual function of both reflecting back the faults of the beholder and offering him or her an ideal image to which he or she can aspire.

\section{IV}

The politics and the ethics to be found in the New Atlantis thus return, as do many of Bacon's heuristic and propaedeutic writings, to a basic set of propositions concerning the necessity of a reform of attitudes towards and practices of thinking and reading about natural philosophy. As Brian Vickers has pointed out, one of Bacon's main achievements was to 'take the vita activa tradition, with its goals of open communication, exchange, knowledge to be used for the benefit of man, and to appropriate it for science'; the New Atlantis is a prime example of this appropriation in action..$^{8}$ In its gesturing towards a possible but highly uncertain future, however, the text goes beyond the general reflections on the ethics of reading which I have sketched here. It offers a reflection on the possible reception of Bacon's own texts and their future fortunes, a subject by which he was considerably exercised. The proleptic gesture is present almost everywhere in his writings. For example, in the Novum Organum he writes: '[I] hold it enough if in the intermediate business [before the sixth part of the Instauratio] I bear myself soberly and profitably, sowing in the meantime for future ages the seeds of a purer truth, and performing my part towards the commencement of the great undertaking', while in his will he (rather more bitterly) bequeathed his 'name and memory' to 'men's charitable speeches, and to foreign nations, and the next ages' ${ }^{49}$

Though Bacon's status as a thinker 'ahead of his time' has often been asserted, $5^{\circ}$ it is important to recognise his conviction that in fact the time was ripe for his ideas and the reforms they 
necessitated: he did not always think of sowing as a solitary occupation. He did, however, make a distinction between the preparation and the fruition of his ideas, and also the different textual forms that would be required for each. In the De interpretatione Naturae Proemium, an undated piece first published by Gruter in I653, he writes that:

those parts of the work which have it for their object to find out and bring into correspondence such minds as are prepared and disposed for the argument, and to purge the floors of men's understandings, I wish to be published to the world and circulate from mouth to mouth: the rest I would have passed from hand to hand, with selection and judgement..$^{\mathrm{I}}$

The New Atlantis can easily be seen as an allegory for this relationship between secrecy and publicity that Bacon imagined for his works. First, he argued, ideas and methods would be developed among a select group and brought to perfection, and then they would be widely disseminated. Bensalem has kept itself concealed from the rest of the world for thousands of years, but at the conclusion of his discourse the Father of Salomon's House signals the end of this isolation: 'I give thee leave,' he tells the narrator, 'to publish [this relation] for the good of other nations; for we are here in God's bosom, a land unknown' (488) - and, of course, the narrator complies, for we are holding in our hands the published narrative. ${ }^{52}$ This suggests, first, that the scientific knowledge of Bensalem is sufficiently perfected to allow its dissemination throughout other lands and, second, that this is a propitious time for scientific reform or revolution in Bacon's Europe.

In its self-reflexiveness and its concern with textual dissemination, the New Atlantis echoes the Redargutio philosophiarum; and other illuminating correspondences between the two works can be identified: the Father of Salomon's House has 'an aspect as if he pitied men' (478), while the face of the lecturer in the Redargutio has become 'habituated to the expression of pity $^{\prime} ;{ }^{53}$ the narrator of the New Atlantis is invited to sit beside the Father as he delivers his 'relation', while the lecturer of the earlier work speaks 'not on a platform or pulpit, but on level with the rest' ${ }^{54}$ Just as in the Redargutio, an illuminating discourse is entrusted to its hearer for further dissemination, and the reader of the text itself is co-opted into this chain of transmission. The 
Redargutio consists, as I have indicated, of a 'lecture' framed by an introductory and concluding narrative: the introduction explains how the main text came into the hands of the writer, while the conclusion ensures the publication of that text: the writer's friend requests that if the narration has found favour, "'will you, when you write on these matters, find room to include my report and not suffer the fruits of my travels to perish." "A fair request,"' replies the writer, "'and I shall not forget." "55 But there is also the possibility of corruption through this transmission: the friend admits that even his report is 'very inferior' to the original lecture, while further telling may lead to greater corruption and to the discourse losing its force. ${ }^{.6}$ Bacon is concerned that his texts and ideas are needed now but that they will only be heeded in the future, if at all. He has what could be called a Cassandra complex - and he explains in De sapientia veterum the problematic results of 'untimely admonitions' ${ }^{57} \mathrm{~A}$ similar concern is present in the New Atlantis: early in the text, the Governor of the Strangers' House explains that very few of the sailors who happened upon the island have ever returned to their own countries, so entranced were they by Bensalem: 'what those few that returned may have reported', he goes on, 'I know not. But you must think, whatsoever they have said could be taken where they came but for a dream' (470). And yet at the very end of the text the Father of Salomon's House explicitly sanctions the narrator to report his experiences and the description of the House to the rest of the world. This raises the question of how it can be guaranteed that he will be believed while those before him have not. Thus the reader of the New Atlantis, coming to the end of this natural-philosophical fable, is placed in the position of an incredulous European meeting the narrator on his return, challenged to believe the account and yet with a space already opened up for disbelief.

This strategy is both a typical Baconian textual joke and, more importantly I would suggest, a challenge to the reader, another mark of the work's pragmatic imperative. If the reader treats the New Atlantis simply as an entertaining fable, or as a model, for discussion, of a perfect society, the text will fail and the reader will have missed a vital opportunity. Instead he or she must have some form of faith in the fable and in the attainability 
of Bacon's natural-philosophical goals: this is why the island is both strange and familiar, and why the list of inventions from Salomon's House mixes things that have already been achieved in Europe with things that appear impossible. The text refuses the prescriptive modes of political writing, but also turns from the dialogic and ironic strategies offered in More's inaugural utopian work. Instead, it both describes and exemplifies in itself a way of reading and an allegory for the new knowledge, suggesting ways of understanding the past and the future, at the same time as describing the kind of society that would result from Bacon's reforms. The projections into the future were, for Bacon, remarkably successful, with members of the Hartlib circle and the Royal Society at various points in the seventeenth century invoking Salomon's House as a model for their own designs of a natural-philosophical College.$^{5^{8}}$ As well as offering a blueprint for such a College, however, it is by now clear, I hope, that the New Atlantis had far-reaching reforming aims. As an extended reflection on the ethics and the politics of the philosopher's relations with past authorities and present and future readers, and on the vital force of the imagination in attaining a 'true vision', it is unrivalled among Bacon's works.

\section{Notes}

I am very grateful to Markku Peltonen, Lucinda Platt and Quentin Skinner for their comments on this chapter.

I Francis Bacon, 'The Plan of the Work', in The Works of Francis Bacon, ed. James Spedding, Robert Leslie Ellis and Douglas Denon Heath, I4 vols (London, Longman, I857-74), vol. IV, p. 32, trans. Spedding.

2 On the Atlantis myth, see Plato, Timaeus and Critias, trans. H. D. P. Lee (Harmondsworth, Penguin, I97I); Timaeus, 24-5, pp. 37-8; Critias, passim.

3 The reference to More's Utopia (I5I6) ('a book of one of your men, of a Feigned Commonwealth') is at p. 478 . On the possible influence of Andreae and Campanella, see Eleanor Dickinson Blodgett, 'Bacon's New Atlantis and Campanella's Civitas Solis: A study in relationships', Publications of the Modern Language Association of America, 46:3 (September I931) 7638o; Michèle Le Doeuff, 'Introduction' to Francis Bacon, La Nouvelle Atlantide, trans. Michèle Le Doeuff and Margaret Llasera (Paris, GF Flammarion, I995), pp. 2 I-2.

4 See Gabriel Plattes, A Description of the Famous Kingdome of Macaria (London, I64I), facsimile reproduction in Charles Webster, Utopian 
Planning and the Puritan Revolution. Gabriel Plattes, Samuel Hartlib and MACARIA (Oxford, Wellcome Unit for the History of Medicine, 1979). Plattes seems to have been especially influenced by the New Atlantis in his description of a 'College of Experience', which bears a close resemblance to Salomon's House (sig. B). On Bacon's reception by the Hartlib circle, see Stephen Clucas, 'In search of "The True Logick": methodological eclecticism among the "Baconian reformers"', in Mark Greengrass, Michael Leslie and Timothy Raylor (eds), Samuel Hartlib and Universal Reformation: Studies in Intellectual Communication (Cambridge, Cambridge University Press, I994), pp. 51-74.

5 On Bacon's followers in the mid- and late seventeenth century, see Christopher Hill, Intellectual Origins of the English Revolution (Oxford, Clarendon Press, I965), Chapter III, 'Bacon and the Parliamentarians', pp. 85-I30; Charles Webster, The Great Instauration: Science, Medicine and Reform I626-166o (London, Duckworth, I975); Antonio Pérez-Ramos, Francis Bacon's Idea of Science and the Maker's Knowledge Tradition (Oxford, Clarendon Press, i988), p. I6.

6 Quoted in Brian Vickers (ed.), Francis Bacon: A Critical Edition of the Major Works (Oxford, Oxford University Press, 1996), p. 785. References to the New Atlantis will be to the edition contained in this volume, pp. 457-89, and will be given parenthetically in the text.

7 See Paolo Rossi, 'Bacon's idea of science', in Markku Peltonen (ed.), The Cambridge Companion to Bacon (Cambridge, Cambridge University Press, I996), pp. $25-46$ (p. 34). I am grateful to Markku Peltonen for this point.

8 Even the title New Atlantis invites comparison with Utopia; cf. More's De optimo reipublicae statu deque nova insula Utopia libellus vere aureus, nec minus salutaris quam festivus (my emphases).

9 Aristotle, The Politics, ed. Stephen Everson (Cambridge, Cambridge University Press, I988) VII.I (I323a), p. I56.

Io See ibid., VII.I-2 (I $\left.323^{\mathrm{a}}-\mathrm{I} 323^{\mathrm{b}}\right)$, pp. I56-7; Aristotle, Ethics, trans. H. Rackham (London, Heinemann, I934) I.iv. I-3 (I095 ${ }^{\text {a }} 4$ ff.), pp. Io-I I.

I I See Ian Box, 'Politics and philosophy: Bacon on the values of peace and war', The Seventeenth Century, VII:2 (Autumn I992) I I3-27; I 2 I, I I 5.

I 2 See, for example, the essay 'Of Simulation and Dissimulation', in Vickers (ed.), Francis Bacon, pp. 349-51.

I3 Specifically the pursuit of greatness, or grandezza; see Markku Peltonen, 'Politics and science: Francis Bacon and the true greatness of states', Historical Journal, 35:2 (I992) 279-305; Peltonen, Classical Humanism and Republicanism in English Political Thought I570-I640 (Cambridge, Cambridge University Press, 1995), Chapter 4, 'Francis Bacon, Thomas Hedley and the true greatness of Britain', pp. I9o-228; p. I95.

I4 See Peltonen, 'Politics and Science', pp. 279-82; David Colclough, "“Of the alleadging of authors": the construction and reception of textual authority in English prose, c. I600-I630' (unpublished D.Phil. dissertation, University of Oxford, I996), pp. 53-4. 
I5 B. H. G. Wormald sees what he identifies as the project of the Great Instauration and Bacon's 'grand strategy' in policy as 'at the very least organically connected' (Francis Bacon: History, Politics and Science I56II626 (Cambridge, Cambridge University Press, I993), p. 8 et passim); while Julian Martin argues that Bacon's intellectual enterprise is primarily a political one, and that his reformation of the grounds of natural philosophy is part of a wider attempt to render the production of knowledge part of the provenance of the state (Francis Bacon, the State, and the Reform of Natural Philosophy (Cambridge, Cambridge University Press, 1992), passim). In The Advancement of Learning, however, Bacon writes that 'the proofs and persuasions of rhetoric ought to differ according to the auditors' (Francis Bacon, The Advancement of Learning, in Vickers (ed.), Francis Bacon, Book II, p. 239). See also Lisa Jardine, Francis Bacon: Discovery and the Art of Discourse (Cambridge, Cambridge University Press, I974), p. I73; Peltonen, 'Politics and science', pp. 303-5; Colclough, “'Of the alleadging of authors"', pp. 50-4.

I6 See Peltonen, 'Politics and science', pp. 294-6.

I 7 On the importance of religious toleration to Bacon's natural philosophy in general and to the New Atlantis in particular, see Le Doeuff, 'Introduction' to Bacon, La Nouvelle Atlantide, pp. 30-5. Le Doeuff notes that ' $\mathrm{La}$ Nouvelle Atlantide est donc strictement oecuménique, et s'écrit sur la base de la plus large concorde judéo-chrétienne qu'on ait imaginée à l'époque' (p. 32).

I8 A glance at Vickers' notes conveys the density of Scriptural reference in the text. For further explication of some allusions, see Elizabeth McCutcheon, 'Bacon and the cherubim: an iconographical reading of the New Atlantis', English Literary Renaissance, 2:3 (Autumn I972) 334-55.

I9 The Governor of the Strangers' House remarks that Solamona found himself 'to symbolize in many things with that king of the Hebrews (which lived many years before him)' (47I).

20 In the Commentarius solutus, notebooks from I608, Bacon writes of 'foundac[ion]. of a college for Inventors past and spaces or Bases for Inventors to come And a Library and an Inginary', going on to outline some of the administrative details that would be involved in running such an institution, including 'qu. of the Maner and praescripts touching Secrecy, tradition, and publication'. He also amasses a heterogeneous list of potential participants, including the Earl of Northumberland, Sir Walter Ralegh, Thomas Hariot, Archbishop Bancroft, Lancelot Andrewes and Prince Henry (two of whom were imprisoned in the Tower of London on treason charges at the time that Bacon was writing); another instance of his willingness to cross serious political and religious divides in the cause of natural philosophy (Works, vol. XI, p. 66). For examples of later attempts to fulfil Bacon's dream, and of the potency of Salomon's House as a model, see Michael Hunter and Paul B. Wood, 'Towards Solomon's House: rival strategies for reforming the early Royal Society', History of Science, 24 (I986) 49-108. 
2 I See Rose-Mary Sargent, 'Bacon as an advocate for cooperative scientific research', in Peltonen (ed.), The Cambridge Companion to Bacon, pp. I467I. There were eleven Italian translations of the Essays between I6I7 and I626, and four in French between I6I9 and I622; De sapientia veterum, originally published in Latin in I6og, went through three editions between I6r9 and 1622 in English, while a French version appeared in I6rg; the expanded Latin Advancement of Learning, the De augmentis scientarium, was first published in I623, while a French collection of Bacon's Oeuvres morales et politiques was published in 1626. See R. W. Gibson, Francis Bacon: A Bibliography of his Works and of Baconiana to the Year 1750 (Oxford, Scrivener Press, 1950) and Gibson, Supplement (privately issued typescript, 1959). On French translations of Bacon, see Michèle Le Doeuff, 'Bacon chez les Grands au siècle de Louis XIII', in Marta Fattori (ed.), Francis Bacon. Terminologia e fortuna nel XVII secolo (Rome, Edizione dell'Ateneo, 1984), pp. I55-78.

22 See, for instance, Amy Boesky, 'Bacon's New Atlantis and the laboratory of prose', in Elizabeth Fowler and Roland Greene (eds), The Project of Prose in Early Modern Europe and the New World (Cambridge, Cambridge University Press, 1997), pp. I38-53.

23 Charles Whitney, 'Merchants of Light: science as colonization in the New Atlantis', in William A. Sessions (ed.), Francis Bacon's Legacy of Texts: 'The Art of Discovery Grows with Discovery' (New York, AMS Press, I990), pp. 255-68; p. 256. So determined is Whitney to read the New Atlantis into a transhistorical colonialist narrative that he appears insensitive to anachronisms such as the notion of a seventeenth-century 'British' 'empire'.

24 Whitney, 'Merchants of Light', p. 257. Boesky, 'Bacon's New Atlantis', also links the New Atlantis with colonialism, suggesting (unconvincingly to my mind) a conjunction between 'scientific and imperial goals [. . .] in the Baconian program' (p. I4I).

25 Whitney, 'Merchants of Light', for example, writes, 'secrecy, one infers, must ensure ridiculously low prices for "light," since the sellers do not know the value of their products' (p. 258).

26 See Paolo Rossi, Francis Bacon: From Magic to Science, trans. Sacha Rabinovitch (London, Routledge and Kegan Paul, I968), p. I2. See further David Colclough, "Non canimus surdis, respondent omnia sylvae": Francis Bacon and the transmission of knowledge', in Philippa Berry and Margaret Tudeau-Clayton (eds), The Texture of Renaissance Knowledge (Palgrave, forthcoming).

27 A development of the Horatian bee topos; see Horace, Odes IV:4, 1l. 27-32, in Horace, Odes and Epodes, trans. C. E. Bennett (London, Heinemann, I927), p. 288. See further Jürgen von Stackelberg, 'Das Bienengleichnis', Romanische Forschungen, 68 (I956) 27I-93. On other uses of the incorporation topos by early-modern writers, see Terence Cave, The Cornucopian Text: problems of writing in the French renaissance (Oxford, Clarendon Press, 1979), p. 37. 
28 See Le Doeuff, 'Introduction' to Bacon, La Nouvelle Atlantide: 'l'identité personelle [. . . est absente du texte [. . . .] il n'ya pas de sujet connaissant' (p. 62).

29 See J. C. Davis, 'Utopianism', in J. H. Burns (ed.), with the assistance of Mark Goldie, The Cambridge History of Political Thought, I450-I700 (Cambridge, Cambridge University Press, I99I), pp. 329-44; p. 343.

30 The doctrine of the Idols appears for the first time in Valerius Terminus of the Interpretation of Nature (Bacon, Works, vol. III, p. 242), and in Temporis Partus Masculus the term 'idolum' appears sixteen times. See Didier Deleule, introduction to Francis Bacon, Récusation des doctrines philosophiques et autres opuscules, trans. Georges Rombi and Didier Deleule, ed. Didier Deleule (Paris, Presses Universitaires de France, 1987), p. II. The doctrine appears most famously in the Novum Organum, in Bacon, Works, vol. IV, pp. 53-68.

3I Temporis partus masculus, in Benjamin Farrington, The Philosophy of Francis Bacon: An Essay on its Development from I603 to I6og with new translations of fundamental texts (Liverpool, Liverpool University Press, i964), p. 62.

32 Farrington, The Philosophy of Francis Bacon, p. 72.

33 'In tabulis nisi priora deliveris, non alia inscripseris. In mente contra: nisi alia inscripseris, non priora deliveris' (Temporis partus masculus, in Bacon, Works, vol. III, p. 539). In this and the following passage I have substituted my own translation for that of Farrington in order to emphasise their very close similarity and to attempt to replicate Bacon's rather complex use of tenses, both of which are obscured by Farrington.

34 'Sane in tabellis non alia inscripseris, nisi priora deliveris; in mente aegre priora deliveris, nisi alia inscripseris' (Redargutio philosophiarum, in Bacon, Works, vol. III, p. 558).

35 As is displayed by his use of the term 'instauration' (renewal or repetition) for his project.

36 Bacon, Works, vol. IV, pp. 26-7.

37 See Aldous Huxley, Island (London, Chatto \& Windus, I962), passim.

38 Farrington, The Philosophy of Francis Bacon, p. I33. Cf. Plato's description of the painful dazzlement of the cave-dwellers if they were exposed to direct light; Republic VII.vii, 5I5d.

39 See Bacon, Novum Organum, aphorism LXVIII, in Works, vol. IV, p. 69. On Bacon's refusal to give the sailors a nationality, see Le Doeuff, 'Introduction' to Bacon, La Nouvelle Atlantide, p. 4o. This authorial diffidence has not prevented critics from declaring them to be either English or Spanish. See Blodgett, 'Bacon's New Atlantis and Campanella's Civitas Solis' 767 (English); Denise Albanese, 'The New Atlantis and the uses of utopia', English Literary History, 57 (I990) 503-28; 508 (Spanish). With typical sagacity, Michèle Le Doeuff and Margaret Llasera note the implication of the sailors' vulnerability and ignorance, pointing out that they are 'à la fois enfants et lecteurs, au total écoliers' (Michèle Le Doeuff and Margaret Llasera, 'Voyage dans la Pensée Baroque', in Francis Bacon, La Nouvelle 
Atlantide, trans. Michèle Le Doeuff and Margaret Llasera (Paris, Payot, I983), p. 95).

$4^{0}$ In the Novum Organum, Bacon outlines the importance of making the kind of natural-philosophical wish-list that the Father's description includes and with which the New Atlantis concludes (in the section headed 'magnalia naturae, praecipue quoad usus humanos'): 'in the work itself of interpretation in each particular subject, I always assign a place to the Human Chart, or Chart of things to be wished for. For to form judicious wishes is as much a part of knowledge as to ask judicious questions' (aphorism XLIX; Works, vol. IV, p. 233).

4I Aristotle, The Politics, II.6, p. 30; cf. VII.4, p. I62.

42 Bacon, Works, vol. IV, p. 57.

43 On the apocalyptic influence, see Brian Vickers' headnote to the New Atlantis in Francis Bacon, ed. Vickers, p. 786.

44 On Bacon as a conservative reformer in the New Atlantis, see Sharon Achinstein, 'How to be a progressive without looking like one: history and knowledge in Bacon's New Atlantis', CLIO, I7:3 (Spring I988) 249-64, which offers an astute analysis only vitiated by its treatment of the text as openly utopian and as a 'summary of Bacon's political teaching' (250).

45 On the topos of the discovery of islands as providing a counter to the notion that all is known, see Le Doeuff, 'Introduction' to Bacon, La Nouvelle Atlantide, p. 49.

46 The Vulgate version is 'plurimi pertransibunt et multiplex erit scientia'. See also Redargutio philosophiarum, in Farrington, The Philosophy of Francis Bacon, p. I32. In a perhaps unintentionally ironic reflection on the mutual dependence of individual research, collective scholarship and extensive financial patronage, this phrase is quoted on the benefactors' plaque in the Bodleian Library, that 'ark of learning' praised by Bacon in letters to his friend. On patronage versus collective action in Bacon, see Le Doeuff, 'Introduction' to Bacon, La Nouvelle Atlantide, pp. I9-2 I.

47 Michèle Le Doeuff notes this important topos, also linking it with Bacon's reformism: 'on remarquera [. . .] que tout y est "comme en Europe" ou "comme chez nous", au degré de perfection près' (Le Doeuff, 'Introduction' to Bacon, La Nouvelle Atlantide, p. 54).

48 Brian Vickers, 'Bacon's so-called "utilitarianism": sources and influence', in Fattori (ed.), Francis Bacon. Terminologia e fortuna, pp. 28I-3I3; p. 3I3. For Bacon's praise of the active life, see Peltonen, Classical Humanism, pp. I $39-45$.

49 Aphorism CXVI: Bacon, Works, vol. IV, p. I04; Works, vol. XIV, p. 539.

50 See, most recently, Perez Zagorin, Francis Bacon (Princeton, Princeton University Press, I998).

5 I Bacon, Works, vol. X, p. 87.

52 The New Atlantis was only printed posthumously, but I assume here that some circulation was intended by Bacon, whether in manuscript or print. 
53 Farrington, The Philosophy of Francis Bacon, p. Io4.

54 Ibid., p. I05.

55 Ibid., p. I33.

56 Ibid., p. I05.

57 See 'Cassandra, siue parrhesia', in Francis Bacon, De sapientia veterum (London, I6o9), sigs. B-B2; cf. Francis Bacon, The Wisedome of the Ancients, trans. Sir Arthur Gorges (London, I6I9), sigs. A-A2 ${ }^{\mathrm{v}}$.

58 Joseph Glanvill, Scepsis Scientifica (London, I665), declares openly that 'Solomon's House, in the NEW ATLANTIS, was a Prophetick Scheam of the ROYAL SOCIETY' (sig. c); see Vickers' headnote in Vickers (ed.), Francis Bacon, pp. 788-9. See also Hunter and Wood, 'Towards Solomon's House', passim. 